\title{
PEMETAAN MINAT BISNIS MAHASISWA DI UNIVERSITAS AMIKOM BERDASARKAN KOMPETENSI
}

\author{
Yusuf Amri Amrullah, Universitas Amikom Yogyakarta \\ amri@amikom.ac.id \\ Anggrismono, Universitas Amikom Yogyakarta \\ anggris@amikom.ac.id
}

\begin{abstract}
ABSTRAK
Penelitian ini bertujuan untuk memetakan minat bisnis mahasiswa prodi S1 informatika dan S-1 sistem informasi di Universitas Amikom Yogyakarta berdasarkan kompetensi prodi pada bidang Tekhnologi Informasi dan Komputer (TIK). Metode yang digunakan dalam penelitian ini menggunakan deskriptif kuantitatif dengan metode pengumpulan data proportional stratified random sampling. Hasil pembahasan menunjukkan bahwa minat bisnis yang dimiliki mahasiswa Universitas Amikom Yogyakarta pada prodi S-1 Sistem Informasi dan S-1 Informatika lebih dari 50\% belum sesuai dengan bidang kompetensinya yaitu TIK. Implikasi dari penelitian ini yaitu mengetahui kesesuaian minat bisnis mahasiswa Amikom dengan kompetensi yang dimiliki pada prodi S-1 informatika dan S-1 sistem informasi.
\end{abstract}

Kata Kunci: Kewirausahaan, Minat, Bisnis, Kompetensi.

\begin{abstract}
This study aims to map the business interests of S-1 informatics study program students and S-1 information systems at Yogyakarta Amikom University based on study program competencies in the field of Information and Computer Technology. The method used in this research using quantitative descriptive method of research with data collection method proportional stratified random sampling. This research result that business interests owned university students in amikom yogyakarta prodi $s-1$ information systems and s-1 information more than $50 \%$ not according to the competence that is Information and computer technology. The implication of this research is knowing the suitability of Amikom students' business interests with the competencies possessed by the undergraduate informatics study program and the undergraduate information system.
\end{abstract}

Keywords: Entrepreneur, Interest, Business, Competence.

\section{PENDAHULUAN}

Kewirausahaan atau entrepreneurship berasal dari bahasa Perancis "entreprendre" yang bermakna perantara (Munjiati et al, 2016). Sedangkan pengertian wirausaha atau entrepreneur adalah mereka yang selalu bekerja keras dan kreatif untuk mencari peluang bisnis, mendayagunakan peluang yang 
diperoleh, dan kemudian merekayasa penciptaan alternatif sebagai peluang bisnis baru dengan faktor keunggulan (Heflin, 2004, dalam Munjiati et al, 2016). Menurut Peter Drucker (Takdir, et al, 2015), penggunaan kata entrepreneur digunakan lebih dari 200 tahun. Krueger dan Carsrud (Yudi Siswadi, 2013)menyatakan bahwa prediktor terbaik untuk beriwausaha yaitu minat berwirausaha. Pada penelitian Gorman et al. (1997) serta Kourilsky dan Walstad (1998) juga menyatakan sumber berdirinya suatu usaha baru mahasiswa yaitu minat berwirausaha pada mahasiswa. Minat wirausaha (entrepreneurial intention) dapat diartikan sebagai langkah awal dari suatu proses pendirian sebuah usaha yang umumnya bersifat jangka panjang (Lee and Wong, 2004). Sejumlah faktor telah diprediksi dapat mempengaruhi minat seseorang untuk berkarir sebagai wirausaha; seperti keinginan untuk menjadi wirausaha, faktor kepribadian, keterampilan wirausaha dan ketersediaan modal (Zain et al, 2010; Kurnianto dan Sulistya, 2012).

Kementerian Koperasi dan Usaha Kecil Menengah (KUKM) mensyaratkan waktu 42 bulan ketahanan untuk seseorang atau badan bisa disebut wirausahawan. Menurut data dari kementerian KUKM (Koperasi dan Usaha Kecil Menengah) tahun 2014, persentase jumlah penduduk Indonesia yang berprofesi sebagai wirausaha kalah jauh jika dibandingkan dengan negara lain di kawasan ASEAN, sebagai contoh di tahun 2014 Singapura memiliki persentase sebanyak $6.1 \%$ dan Malaysia yang memiliki persentase $4.25 \%$. Sementara negara-negara maju seperti China memiliki rasio jumlah wirausaha dibandingkan jumlah penduduknya sebesar 10.25\% dan Amerika Serikat di tahun 2014 memiliki rasio sebesar $11.71 \%$.

Namun dari mahasiswa perguruan tinggi di Indonesia yang bekerja hanya sebesar 32,62\% pada tahun 2016. Jumlah ini naik dari $27.21 \%$ di tahun 2015 (Gambar 1). Pertumbuhan kewirausahaan di suatu negara terletak pada peran perguruan tinggi dengan menyelenggarakan pendidikan kewirausahaan (Zimmerer, 2002).

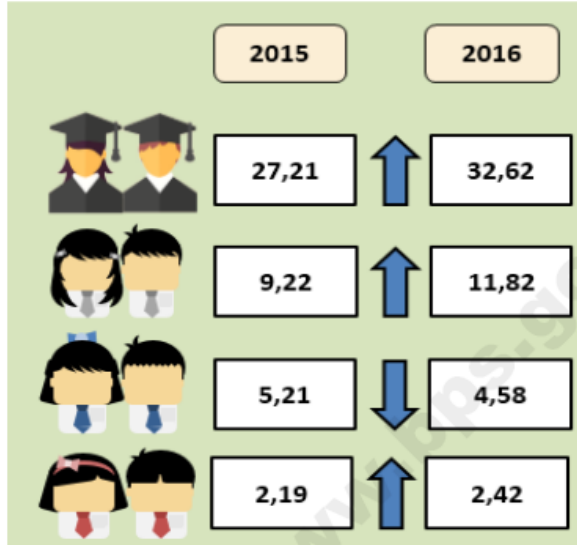

Sumber: BPS - Susenas KOR 2015 dan 2016

Gambar 1. Persentase Siswa Umur 10 - 14 Tahun yang Bekerja Menurut Jenjang

Dalam proses kegiatan belajar mengajar Unversitas Amikom Yogyakarta mengedepankan kegiatan kewirausahaan, sehingga menjadi hal yang sangat normal apabila salah satu misi andalan adalah menjadikan $30 \%$ lulusannya menjadi sarjana pengusaha. Hal ini dibuktikan dengan tingginya jumlah para 
alumni yang memilih bekerja sebagai pengusaha yaitu sebanyak 309 orang atau kurang lebih 23\% pada tahun 2015. Dengan rincian penyumbang alumni wirausaha terbanyak adalah dari Prodi S1 Teknik Informatika yaitu 186 orang atau sekitar 30\% dari total alumni S1 Teknik Informatika yang terlacak, atau sekitar $60 \%$ dari total seluruh alumni wirausaha angkatan 2015 sejumlah 309 (BPC Universitas Amikom Yogyakarta, 2015).

Sedangkan pada tahun 2016 dari hasil tracer study di dapatkan bahwa $12 \%$ alumni memilih berwiraswasta dari total 1824 alumni yang berhasil di hubungi (BPC Universitas Amikom Yogyakarta, 2016). Dengan rincian $12 \%$ dari 1824 yaitu 222 alumni menjadi wirausaha yaitu 159 alumni bekerja sebagai wirausaha yang sesuai dengan kompetensi (Tekhnologi Informasi dan Komputer) dan 63 alumni bekerja sebagai wirausaha non Tekhnologi Informasi dan Komputer (tidak sesuai kompetensi). Berdasarkan data diatas maka kami tertarik untuk meneliti Minat bisnis mahasiswa Universitas Amikom Yogyakarta studi kasus prodi informatika dan prodi sistem informasi berdasarkan kompetensi yang bertujuan untuk memetakan minat bisnis mahasiswa Universitas Amikom Yogyakarta studi kasus prodi informatika dan prodi sistem informasi berdasarkan kompetensi.

Tujuan dari penelitian ini yaitu ; mengetahui minat bisnis mahasiswa prodi informatika dan sistem informasi Universitas Amikom Yogyakarta berdasarkan kompetensi. Mengetahui implementasi wirausaha mahasiswa prodi informatika dan sistem informasi Universitas Amikom Yogyakarta berdasarkan kompetensi.

Rumusan masalah yang melatarbelakangi penelitian tersebut yaitu bagaimana kondisi wirausaha mahasiswa prodi informatika dan prodi sistem informasi apakah sudah sesuai dengan kompetensi atau bidang yang mereka tekuni.

\section{METODE PENELITIAN}

Metode penelitian ini menggunakan deskriptif kuantitatif. Metode penelitian ini bertujuan untuk menggambarkan secara sistematis fakta, karakteristik populasi atau bidang tertentu (Nurlina et al, 2017). Peneliti mengungkapkan penelitian deskriptif kuantitatif. Menurut Nurlina et al, 2017, penelitian kuantitatif menghasilkan penjelasan tentang suatu masalah dan juga menghasilkan generalisasi. Generalisasi adalah suatu kenyataan kebenaran yang ada dalam realitas suatu masalah yang diperkankan akan berlaku pada suatu populasi tertentu.

Sugiono (2013) menyatakan bahwa metode kuantitatif dapat diartikan sebagai metode penelitian yang berlandaskan pada filsafat positivisme, digunakan untuk meneliti pada populasi atau sampel tertentu, pengumpulan data menggunakan instrumen penelitian, analisis data bersifat kuantitatif/statistik dengan tujuan untuk menguji hipotesis yang telah ditetapkan, dan metode kuantitatif ada 2 macam, metode eksperimen dan metode survei.

Penelitian survey pada umumnya dilakukan untuk mengambil suatu generalisasi dari pengamatan yang tidak mendalam. walaupun metode survei ini tidak memerlukan kelompok kontrol seperti halnya pada metode 
eksperimen, namun generaliasasi yang dilakukan bisa lebih akurat bila digunakan sampel yang representatif (David Kline:1980, dalam Sugiono, 2017).

Metode pengumpulan data yang digunakan oleh peneliti yaitu dengan observasi dan penyebaran kuisioner dengan menggunakan Stratified Random Sampling adalah pengambilan sampel berdasarkan strata yang ada dalam populasi. (Muhyiddin, et al, 2017).

\section{HASIL PENELITIAN DAN PEMBAHASAN}

Responden atau sampel pada penelitian ini terdiri dari 2 prodi yaitu prodi S-1 Sistem Informasi dan S-1 Informatika dengan total responden 372 orang, dengan presentase $58 \%$ prodi S-1 Informatika atau 217 orang responden dan $42 \%$ dari S-1 Sistem Informasi atau 155 orang responden.

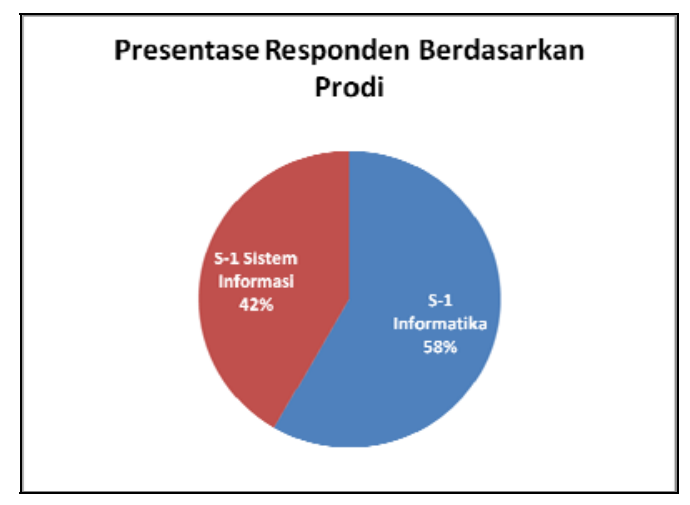

Gambar 2. Presentase Responden

Jumlah pertanyaan yang digunakan untuk mengukur masing-masing dimensi kompetensi mahasiswa Informatika ini tidak sama. Dalam penelitian ini terdapat 11 pertanyaan kepada mahasiswa Informatika terkait kompetensi mereka. Dari 11 pertanyaan ini, dikelompokkan kedalam 3 kompetensi inti yaitu; pemrograman, multimedia dan film kartun serta jaringan komputer.

Sedangkan untuk mahasiswa Sistem Informasi diberikan 6 pertanyaan terkait kompetensi mereka. Keenam pertanyaan ini mewakili 6 kompetensi, yaitu:

1. SI berbasis Desktop

2. SIA

3. E-Commerce

4. Multimedia

5. Animasi 2D 3D

6. Kreasi Game PC, Mobile

Skor untuk masing-masing pertanyaan ini menggunakan skala Likert yang dibagi dalam lima kategori yaitu mulai dari Sangat Tidak Setuju, Tidak Setuju, Netral, Setuju, Sangat Setuju. Skor untuk masing-masing butir pertanyaan ini berjarak 1 yang dimulai dari 1 (Sangat Tidak Setuju) sampai 5 (Sangat Setuju). Untuk setiap jawaban dengan skor 4 (setuju) dan skor 5 
(Sangat Setuju) maka menunjukkan bahwa mahasiswa tersebut memiliki kompetensi pada bidang kompetensi yang ditanyakan.

Dari hasil uji validitas diketahui untuk jumlah sampel mahasiswa Informatika sebanyak 39 orang, maka diperoleh $\mathrm{r}$ tabel sebesar 0.316 . Sedangkan untuk jumlah sampel mahasiswa Sistem Informasi sebanyak 33 orang, maka diperoleh $\mathrm{r}$ tabel sebesar 0.344. Untuk sampel gabungan dengan jumlah sampel sebanyak 72 orang maka didapatkan $r$ tabel sebesar 0.2319.

Pada saat dilakukan pengujian validitas terhadap 11 pertanyaan yang ditanyakan kepada mahasiswa Informatika terkait kompetensi yang dimilikiya, ditemukan 2 pertanyaan yang harus dikeluarkan karena dianggap tidak valid. Sehingga hanya 9 pertanyaan yang layak digunakan dalam penelitian ini.

Untuk mahasiswa Sistem Informasi ditanyakan sebanyak 6 pertanyaan terkait kompetensi yang dimilikinya. Namun pada saat dilakukan uji validitas, terdapat 1 pertanyaan yang harus dikeluarkan karena dianggap tidak valid, sehingga pertanyaan yang digunakan hanya berjumlah 5 buah.

Dari 9 pertanyaan mengenai kompetensi mahasiswa prodi Informatika, sebanyak 23,78\% mahasiswa setuju dan sangat setuju bahwa mereka berkompeten dalam bidang pemrograman. Sebanyak 20,74\% mahasiswa setuju dan sangat setuju bahwa kompeten dalam bidang Multimedia dan Animasi, sementara 23,04\% mahasiswa menyatakan setuju dan sangat setuju berkompeten dalam bidang Jaringan Komputer.

Dari 5 pertanyaan mengenai kompetensi mahasiswa prodi Sistem Informasi, sebanyak $31,61 \%$ mahasiswa setuju dan sangat setuju memiliki kompetensi dalam bidang Sistem Informasi berbasis Desktop. 27,1\% mahasiswa menyatakan setuju dan sangat setuju memiliki kompetensi dalam dibidang Sistem Informasi Akuntansi. Skor paling tinggi yaitu 39,35\% mahasiswa menyatakan setuju dan sangat setuju memiliki kompetensi dalam bidang E-Commerce. Sementara sebanyak $27,1 \%$ mahasiswa setuju dan sangat setuju memiliki kompetensi dalam bidang Animasi 2D dan 3D, dan yang terakhir sebanyak $21,29 \%$ mahasiswa menyatakan setuju dan sangat setuju memiliki kompetensi dalam bidang Kreasi game PC dan Mobile. Hasil analisis penguasaan kompetensi dapat disimak pada tabel 1 .

Tabel 1. Penguasaan Kompetensi Oleh Mahasiswa

\begin{tabular}{llc}
\hline \multicolumn{1}{c}{ PENGUASAAN KOMPETENSI OLEH MAHASISWA } \\
\hline INFORMATIKA & Pemrograman & $23.78 \%$ \\
& Multimedia dan Film & $20.74 \%$ \\
& Kartun & \\
\multirow{3}{*}{ SISTEM } & Jaringan komputer & $23.04 \%$ \\
INFORMASI & SI berbasis Desktop & $31.61 \%$ \\
& SIA & $27.10 \%$ \\
& E-Commerce & $39.35 \%$ \\
& Animasi 2D 3D & $27.10 \%$ \\
& Kreasi Game PC, Mobile & $21.29 \%$ \\
\hline
\end{tabular}

Bila dikaitkan dengan minat untuk berwirausaha, maka sebagian besar responden mahasiswa $(72,24 \%)$ menyatakan setuju dan sangat setuju bahwa mereka memiliki minat untuk melakukan kegiatan berwirausaha. Sementara 
ketika dikaitkan minat wirausaha dengan kompetensi yang dimilikinya maka didapatkan hasil sebanyak $24,66 \%$ dari responden memiliki minat berwirausaha sesuai dengan kompetensi yang dimilikinya (Tabel 2).

Tabel 2. Minat Wirausaha

\begin{tabular}{ll}
\hline Minat Mahasiswa untuk berwirausaha & $72.24 \%$ \\
\hline $\begin{array}{l}\text { Minat Mahasiswa berwirausaha sesuai } \\
\text { kompetensi }\end{array}$ & $24.66 \%$ \\
\hline
\end{tabular}

Selain mengisi kuesioner, responden juga diminta untuk menjawab pertanyaan secara lisan (wawancara) yang dilakukan pada tanggal 14 November 2017 di Universitas Amikom Yogyakarta. Dari beberapa responden yang diwawancara, beberapanya sudah memiliki usaha yang telah berjalan, contohnya Muhammad Maulana Rizqananda yang telah memiliki usaha dalam bidang produk informasi kreatif atau interaktif berbasis multimedia (company profile multimedia, iklan media cetak) dan Fajar Muhammad Samole yang memiliki usaha dalam bidang Pemrograman website, web E-commerce.

\section{SIMPULAN}

Berdasarkan hasil pembahasan menunjukkan bahwa minat bisnis yang dimiliki mahasiswa Universitas Amikom Yogyakarta pada prodi S-1 Sistem Informasi dan S-1 Informatika lebih dari $50 \%$ belum sesuai dengan bidang kompetensinya yaitu IT. Implikasi dari penelitian ini yaitu hendaknya tugas tugas pada mata kuliah kewirausahaan lebih diarahkan ke arah IT. Pada penelitian selanjutnya disarankan untuk lebih mendalami faktor - faktor minat bisnis mahasiswa sehingga akan relevan dengan kompetensi mahasiswanya.

\section{DAFTAR RUJUKAN}

Badan Pusat Statistik (BPS), Indikator Pendidikan BPS-RI, Susenas 1994 2016 Update tanggal 22 Maret 2017. (Online : Https://www.bps.go.id/linkTabelStatis/view/id/1525, diakses juni, 2017.

Tim Business Placement Center. (t.t.). Tracer Study STMIK AMIKOM Yogyakarta (2015 ed.). Yogyakarta: BPC Amikom.

Tim Business Placement Center. (t.t.). Tracer Study STMIK AMIKOM Yogyakarta (2016 ed.). Yogyakarta: BPC Amikom

Kourilsky, M.L. \& Walstad, W.B. 1998. Entrepreneurship and Female Youth: Knowledge, Gender Differences and Educational Practices. Jurnal of Business Venturing. 13(1): $77-88$. 
Kurnianto, B. S. \& Sulistya E. P. 2012. Menumbuhkembangkan Minat Berwirausaha bagi Mahasiswa Di Lingkungan Perguruan Tinggi. Prosiding Seminar \& Konferensi Nasional Manajemen Bisnis, (Mei).

Lee, S. H., Wong, P. K. 2004. An Exploratory Study of Technopreneurial Intentions; A Career Anchor Perspective. Journal of Business Venturing, 19 (1) : 7-28.

Muhyiddin, Nurlina T., M. Irfan Tarmizi, dan Anna Yulianita. 2017. Metodologi Penelitian Ekonomi dan Sosial. Jakarta. Salemba Empat. 72.

Munawaroh, Mujiati. Rimiyati, Hasnah dan Fajarwati. 2016. Kewirausahaan Untuk Program Strata 1. Yogyakarta. LP3M UMY.

Siswadi, Yudi. 2013. Analisis Faktor Internal, Faktor Eksternal dan Pembelajaran Kewirausahaan yang Mempengaruhi Minat Mahasiswa dalam Berwirausaha. Jurnal Manajemen dan Bisnis, Vol 13, no. 01.

Sugiyono. 2013. Metode Penelitian Pendidikan Pendekatan Kuantitatif, Kualitatif, dan R\&D. Bandung: Alfabeta.

Sugiyono. 2016. Metode Penelitan Manajemen. Bandung: Alfabeta.

Sugiyono. 2017. Metode Penelitian Kuantitatif, Kualitatif, dan R\&D. Bandung: Alfabeta

Takdir, et. al. 2015. Kewirausahaan. Yogyakarta. Wijaya Mahadi Karya. 1.

Zain, et al. 2010. Entrepreneurship Intention Among Malaysian Business Students. Canadian Social Science, 6(3): 34-44.

Zimmerer, W.T. 2002. Essentials of Entrepreneurship and Small Business Management. Third Edition. New York: Prentice-Hall. 
